\title{
Two New Records of the Family Miridae (Hemiptera: Heteroptera) in Korea
}

\author{
Jongwoon Seong, Gwan-Seok Lee* and Seunghwan Lee ${ }^{1}$ \\ Applied Entomology Div., Dept. of Agricultural Biology, National Academy of Agricultural Science, RDA, 61 Seodun-dong, Gwonseon-gu, \\ Suwon-si, Gyeonggi-do, 441-853 \\ ${ }^{1}$ Lab. of Insect Biosystematics, Program in Entomology, School of Agricultural Biotechnology, Seoul National University, San 56-1 Shillim-dong, \\ Gwanak-gu, Seoul 151-921, Korea
}

\section{장님노린재과(노린재목) 한국미기록 2종에 대한 보고}

성종운 · 이관석* · 이승환 ${ }^{1}$

농촌진흥청 국립농업과학원 농업생물부 곤충산업과, ${ }^{1}$ 서울대학교 농업생명과학대학 농생명공학부 곤충학전공

\begin{abstract}
Two species of Miridae, Pachylygus nigrescens (Kerzhner 1977) and Deraeocoris yasunagai Nakatani 1995, are reported for the first time from Korea. The brief information on them is presented with the photos of specimens.
\end{abstract}

KEY WORDS : Pachylygus nigrescens, Deraeocoris yasunagai, New records, Miridae

초 록 : 2종의 장님노린재(Pachylygus nigrescens (Kerzhner 1977), Deraeocoris yasunagai Nakatani 1995)의 국내분포를 처음으로 확인하고 형태적 특징과 분포 등 종 동정에 필요한 정보를 성충 사진과 함께 간략히 기술하였다.

검색어 : Pachylygus nigrescens, Deraeocoris yasunagai, 미기록종, 장님노린재과

The Miridae, plant bugs, is the largest family of Heteroptera with more than 10,000 described species in the world. They are so diverse, abundant, and widely distributed in almost all zoogeographic regions except Antarctica, so they have been considered as one of ecologically successful groups (Wheeler, 2001). Plant bugs, except Isometopinae which is a small subfamily of the Miridae, have no ocelli in their head, hemelytral membranes with 1 or 2 closed cells, and the cuneus demarcated by a conspicuous costal fracture, which are very useful to separate them from other terrestrial heteropterans. Many plant bugs are important in agriculture as pests or natural enemies for biological control.

Since Miyamoto \& Lee (1966) first recorded three species of the Miridae from Jeju island, many species including new species have been added to the Korean fauna by several Korean and foreign researchers. Presently, the Korean fauna of the Miridae is represented by approximately 210 species (Kwon et al., 2001; Seong \& Lee, 2007; Cho et al., 2008). In the course of our taxonomic

*Corresponding author. E-mail: gslee12@rda.go.kr 
study on the Miridae, we found two newly recorded species from Korea, Pachylygus nigrescens (Kerzhner 1977) and Deraeocoris yasunagai Nakatani 1995. Brief taxonomical and biological information on them is presented with some photos. All specimens examined in this study are deposited in National Academy of Agricultural Science [NAAS] and Seoul National University [SNU].

The abbreviations for administrative districts used herein are as follows: CB Chungcheongbuk-do, GG Gyeonggi-do. All measurements in this study are given in millimeters, and the definitions and their abbreviations follow Seong \& Lee (2007).

\section{Systematic Accounts}

\section{Genus Pachylygus Yasunaga 1994}

Pachylygus Yasunaga, 1994: 124. Type species by original designation: Orthops japonicus Kerzhner 1977.

Remarks. The genus Pachylygus Yasunaga 1994 is first recorded in Korea in this study. Yasunaga (1994) erected this genus to accommodate three Pinalitus species which are apparently different from other congeners, so-called 'true' Pinalitus species, in host plants and structures in male and female genitalia. This genus is characterized by the rather tumid body, the strongly arched scutellum, the characteristic spicule on the vesica, the sclerotized plate in front of the gonopore, and the enlarged sclerotized rings in female genitalia (Yasunaga, 1994).

Discussion. Presently, this genus includes four species which have been reported only from Japan and Russia. All records of Russia are, however, from Kunashir island, the southernmost Kurile island which is very close to Hokkaido, Japan. For this reason, Yasunaga et al. (2002) considered discreetly that this genus would be endemic to the Japanese Archipelago. This record from Korea is based on only one female specimen of $P$. nigrescens, so it cannot rule out the possibility that it was collected accidentally. Therefore, more subsequent collecting records are required to ensure more certainly distribution of this genus in Korea.

\section{Pachylygus nigrescens (Kerzhner 1977) 검정솟 은등장님노린재 (신칭) [Fig. 1. A-B]}

Orthops nigrescens Kerzhner, 1977: 12. (Type locality: Russia; Kunashir Is.)

Pinalitus nigrescens: Kerzhner, 1988: 70.

Pachylygus nigrescens: Yasunaga, 1994: 126; Kerzhner
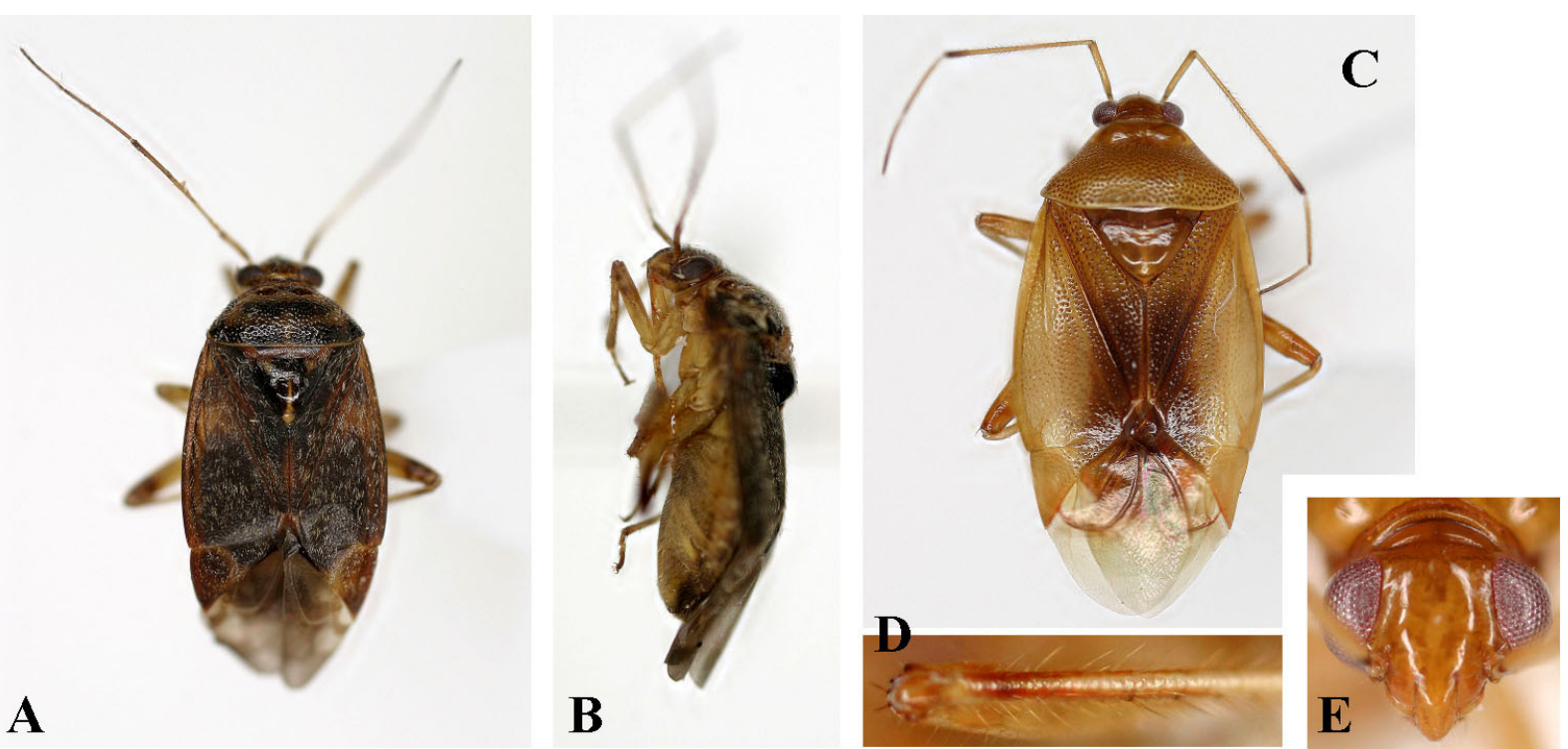

Fig. 1. Adults of $P$. nigrescens and D. yasunagai. A-B: P. nigrescens (A: body in dorsal view; B: body in lateral view); C-E: D. yasunagai (C: body in dorsal view; D: tibia in lateral view; $\mathrm{E}$ : head in front view). 
\& Josifov, 1999: 135; Yasunaga et al., 2001: 254; Yasunaga et al., 2002: 9.

Description. Body oval; dorsum fuscous, covered with reclining silky hairs. Head vertical, brown, but usually vertex and frons dark brown medially, covered with short erect or reclining silky hairs; vertex with a distinct basal transverse carina; tylus entirely dark brown; inner part of bucculae red. Antenna brown; segment I partly infuscated; apical half of segment II, entire segments III and IV dark brown. Rostrum brown, reaching metacoxa; segment I slightly tinged with red apically. Pronotum shiny, densely and deeply punctate, fuscous with irregular dark brown or black marks; pronotal collar brown, but sometimes dark brown anteriorly, broader than antennal segment I, and covered rather densely with reclining silky hairs. Scutellum shiny, strongly swollen, and dark brown or black with a pale median stripe and two bilateral basal spots; mesoscutum densely covered with silky hairs. Pleura yellowish brown; metathoracic scent efferent system yellowish brown. Hemelytra fuscous, but inner part of clavus and apical half of corium dark brown or black, densely covered with silky reclining hairs and rather long silvery hairs; apical part of cuneus slightly tinged with red; membrane grayish somber brown with pale veins. Leg brown; apical part of femur and basal part of tibia dark brown; tibial spines pale brown, originating from dark brown spots; tarsal segment III dark brown. Abdomen pale or yellowish brown, partly infuscated, with silky reclining hairs.

Materials examined. [NAAS] CB 1 ㅇ, Mt. Joryeongsan, Wonpung, Yeonpung, Goesan, 29.viii. 2002, Gwan-Seok Lee.

Measurements. (female) MBL: 5.5. MBW: 2.6. PW: 2.0. BL: 4.6. HW: 1.2. VW: 0.5. Ant. I: 0.5. Ant. II: 1.8 . Ant. III: 1.1. Ant. IV: 0.7. MFL: 1.9. MTL: 2.6.

Distribution. Korea (Central), Japan (Hokkaido, Honshu, Rishiri Is.), Russia (Kunashir Is.).

Remarks. $P$. nigrescens is very similar with Cyphodemidea saundersi (Reuter 1896) and Peltidolygus scutellatus (Yasunaga \& Lu 1994), but it can be considerably distinguished from the latters by the fuscous cuneus, a little larger body, and uniformly distributed silvery setae on hemelytra. It is known to be associated with Kalopanax pictus (Araliaceae) (Yasunaga et al., 2002).

\section{Genus Deraeocoris Kirschbaum 1856}

Deraeocoris Kirschbaum, 1856: 191, 208. Type species: Capsus medius Kirschbaum 1856 (= Cimex olivaceus Fabricius 1777).

Remarks. This genus is characterized by the polished body and distinctly punctured dorsum. About 200 species have been recorded throughout the world, and almost all species are known as predators of other arthropodas. Some taxonomists are doubtful about the monophyly of this genus. To date, 15 species have been reported in the Korean peninsula. Some species, D. pulchellus (Reuter 1906) and D. ulmi Josifov 1983, are often observed to overwinter as adults under the bark of Zelkova serrata (Ulmaceae).

\section{Deraeocoris yasunagai Nakatani 1995 검정줄무 늬장님노린재(신칭) [Fig. 1. C-E]}

Deraeocoris yasunagai Nakatani, 1995: 408; Kerzhner \& Josifov, 1999: 46; Yasunaga et al., 2001: 200. (Type locality: Japan; Minamitakaki, Nagasaki).

Description. Body oval, shiny; dorsum red or reddish brown (often become yellowish brown during the drying process), with fuscous or dark brown punctures. Head small, oblique, shiny, reddish brown; vertex lacking basal transverse carina. Antenna pale or yellowish brown; segment I dark brown basally and red or reddish brown apically; segments II-IV dark brown apically. Rostrum pale or yellowish brown, reaching apex of metacoxa; apical part of segment IV dark brown. Pronotum shiny, reddish brown, densely and deeply punctured excluding calli; calli swollen, not punctate. Scutellum shiny, pale reddish brown, swollen, not punctate. Pleura shiny, reddish brown; metathoracic scent efferent system rather pale. Hemelytra shiny, reddish brown with a characteristic dark brown or black median stripe along inner margin of clavus and corium, densely and deeply punctate; mem- 
brane translucent with red veins. Leg pale or yellowish brown; femur with red spots apically; tibia with a longitudinal red stripe on basal 2/3 of outer margin. Abdomen shiny, reddish brown.

Materials examined. [SNU] GG 10", Kwanak Arboretum, Manan, Anyang, 4.viii.2008, Sung Hoon Jung \& Ram K. Duwal; [NAAS] GG 1 , , Mt. Taehwasan, Sangrim, Docheok, Gwangju, 5.viii.1998, Jeong-Bae Jeon.

Measurements. (male/ female) MBL: 4.6/ 5.6. MBW: 2.3/ 2.7. PW: 2.1/ 2.2. BL: 4.0/ 4.5. HW: 1.0/ 1.0. VW: 0.4/ 0.4. Ant. I: 0.7/ 0.6. Ant. II: 1.9/ 1.9. Ant. III: 0.7/ 0.8. Ant. IV: 0.6/ 0.7. MFL: 1.7/ 1.9. MTL: 2.3/ 2.5 .

Distribution. Korea (Central), Japan (Honshu, Kyushu, Shikoku).

Remarks. This species can be readily distinguished from other Korean congeners by the characteristic median dark brown stripe along the inner margin of the clavus and the corium, and longitudinal reddish brown stripes on the outer margin of tibiae.

\section{Literatures Cited}

Cho, Y.J., Y.J. Kwon, and S.J. Suh. 2008. First record of the genus Adelphocorisella Miyamoto and Yasunaga (Hemiptera: Miridae) from Korea. Entomol. Res., 38(3): 226-228.

Kerzhner, I.M. 1977. New and little-known species of Heteroptera from the Far East of the USSR. Proceedings of the Zoological
Institute Academy of Sciences of the USSR 62(1976): 6-35 (in Russian).

Kerzhner, I.M. 1988. New and little-known Heteropterous insects (Heteroptera) from the Far East of the USSR (1987): 1-83. Academy of Sciences of the USSR, Far East Branch, Vladivostok (in Russian).

Kerzhner, I.M. and M. Josifov. 1999. Catalogue of the Heteroptera of the Palearctic Region, Vol. 3, Eds. B. Aukema \& C. Rieger, Cimicomorpha II: Miridae. xiv +577 pp. Netherlands Entomological Society, Amsterdam.

Kwon, Y.J., S.J. Suh, and J.A. Kim, 2001. Hemiptera. Economic Insects of Korea 18. Ins. Koreana Suppl. 25: 1-513.

Miyamoto, S. and C.E. Lee. 1966. Heteroptera of Quelpart island (Chejudo). Sieboldia 3: 313-426.

Nakatani, Y. 1995. Deraeocoris kimotoi Miyamoto and its allies of Japan, with description of a new species (Heteroptera: Miridae). Jpn. J. Ent. 63(2): 399-411.

Seong, J. and S. Lee. 2007. Taxonomic notes on two Apolygus species (Heteroptera: Miridae: Mirinae) in Korea. J. Asia-Pacific Entomol. 10(4): 323-327.

Wheeler, A.G, Jr. 2001. Biology of the plant bugs (Hemiptera: Miridae): pests, predators, opportunists. 507pp+xxiv. Cornell University Press, New York.

Yasunaga, T. 1994. Pinalitus Kelton (Heteroptera, Miridae) and its allied genera of Japan, with descriptions of new genera and species. Jpn. J. Ent. 62(1): 115-131.

Yasunaga, T., M.D. Schwartz \& F. Chérot. 2002. New genera, species, synonymies, and combinations in the "Lygus complex" from Japan, with discussion on Peltidolygus Poppius and Warrisia Carvalho (Heteroptera, Miridae, Mirinae). Am. Mus. Novit. 3378: $1-26$.

Yasunaga, T., M. Takai, T. Kawasawa, and Y. Nakatani. 2001. A field guide to Japanese bugs II - terrestrial heteropterans. 350pp. Zenkoku Noson Kyoiku Kyokai Publishing, Tokyo (in Japanese).

(Received for publication January 5 2009;

revised March 5 2009; accepted March 7 2009) 